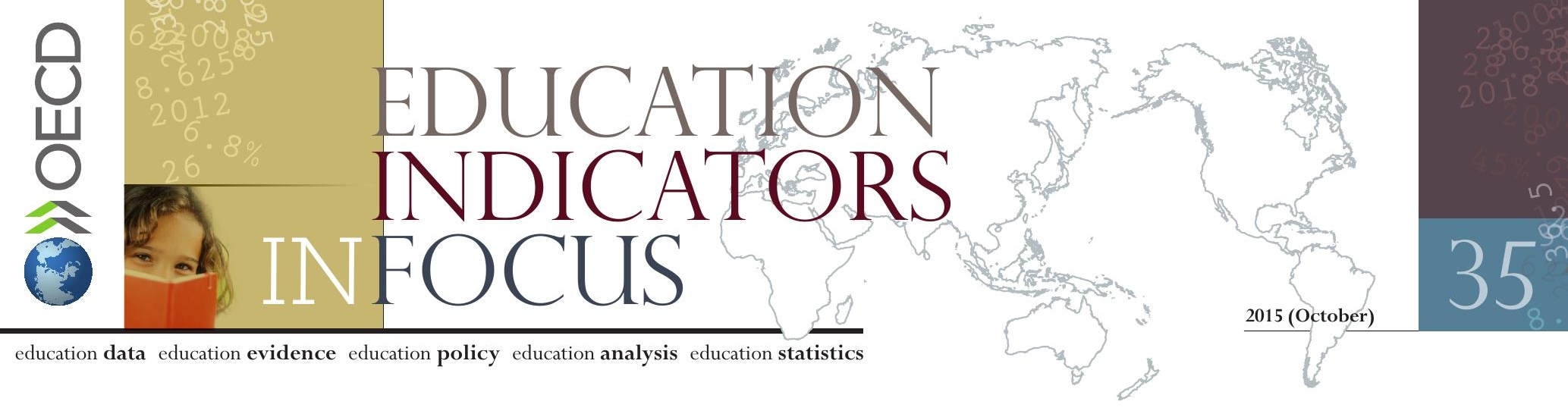

\title{
How do differences in social and cultural background influence access to higher education and the completion of studies?
}

- Parents' level of education still greatly influences that of their children: individuals are 4.5 times more likely to attend higher education if one of their parents has a higher education degree than if both their parents have below upper secondary education.

- Inequalities in higher education reflect to a great extent what happened earlier in an educational career. Upper secondary students from disadvantaged backgrounds are less likely to perform well in PISA assessments, less likely to complete upper secondary education and less likely even to aspire to attend higher education.

- Nevertheless, higher education institutions still have an important role to play in reducing inequalities. Policies must aim to make higher education more accessible for students from disadvantaged backgrounds as well as to support these students and improve their success at this level.

Participation in higher education has been expanding considerably. Between 1995 and 2012, entry rates into higher education increased by almost 20 percentage points on average across OECD countries (OECD, 2014). Increase in participation has translated into an increase in educational attainment, and in 2013 about one in three adults in OECD countries held a higher education qualification (OECD, 2015). Given the strong links between higher education and earnings, employment, overall social progress and the well-being of individuals, this expansion can serve as an important engine of social mobility if everyone can benefit from it. However, inequalities in both access to and success in higher education remain high.

\section{Students' background is still a strong determinant of whether they reach higher education- and whether they succeed.}

Although access to higher education has been expanding, parents' level of education still influences their children's educational attainment. On average across countries participating in the Survey of Adult Skills, a product of the OECD Programme for the International Assessment of Adult Competencies (PIAAC) (2012), more than half of 20-34 year-olds in higher education have at least one parent with that level of education, and slightly more than one-third have at least one parent with upper secondary education as their highest level of attainment. By contrast, the proportion of 20-34 year-old students in higher education whose parents have not completed an upper secondary education is small: only about one higher education student in ten has parents with below upper secondary education (OECD, 2014).

Assessing inequalities in access to higher education is a crucial initial step towards designing policies to reduce them. A basic measure of educational mobility is the odds ratio, which compares the relative likelihood of individuals having a higher education degree if their parents have upper secondary or higher education compared with that of people whose parents have only below upper secondary education. Across countries with available data, the odds ratio is on average twice as great if at least one parent attained upper secondary or post-secondary non-tertiary education, and 4.5 times as great if at least one parent attained higher education (Figure 1). The odds ratio, however, varies widely between countries: in Italy individuals whose parents have higher education are almost 10 times more likely to have a higher education degree than those whose parents have below upper secondary education, whereas in Korea individuals are equally likely to have a higher education degree, independent of parental education.

Similarly, everywhere apart from Australia and Canada, immigrants are less likely than the offspring of natives to have higher education degrees. This is true even for those who arrive in the host country before the age of 15. Indeed, arriving before the age of 15 does not make immigrants more likely to have a higher education degree, only less likely to have no or low education (OECD/European Union, 2015). 
Parental educational attainment still considerably influences access to and participation in higher education. But this is also true for completion. The evidence suggests that dropping out is a particular problem for students from a disadvantaged socio-economic background. A study that compared access and retention rates in higher education in ten countries found that socioeconomic status has the greatest impact on students dropping out, dominating all other factors such as ethnicity and gender (Thomas and Quinn, 2006). First-generation students (i.e. when no one in the family has attended higher education) are also more likely to drop out. A study conducted in Italy (Aina, 2010) found that undergraduates with fathers or both parents who did not attend higher education were less likely to complete their studies.

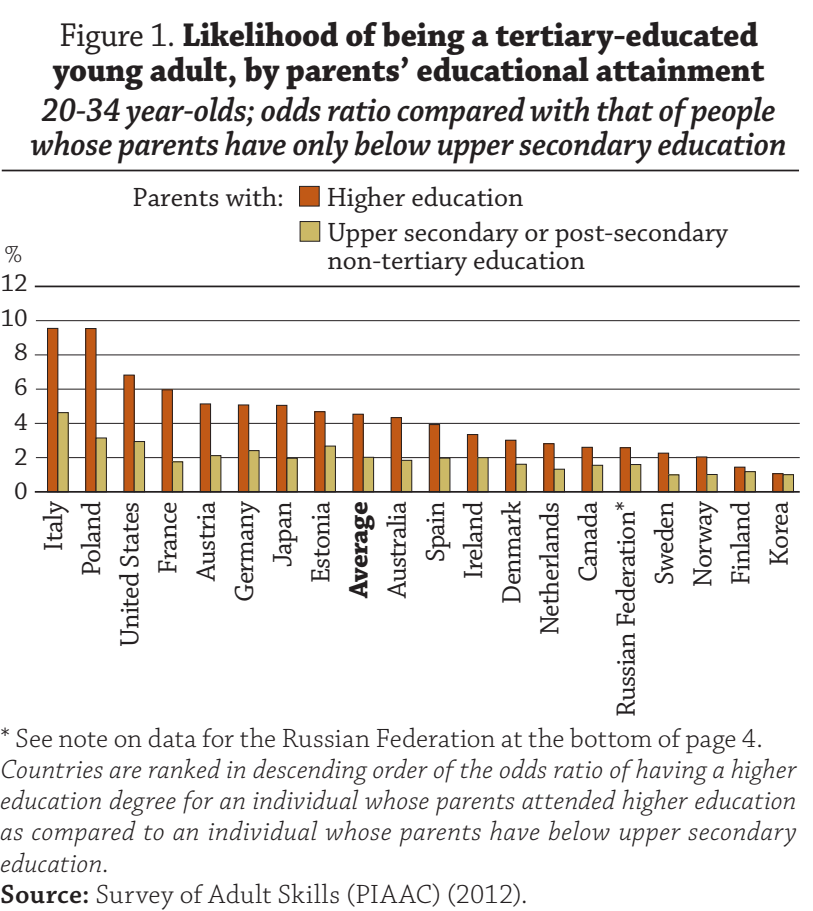

Figure 2. Completion rate of upper secondary programmes by parents' education (within $N$ years of study, where $N$ = theoretical duration)

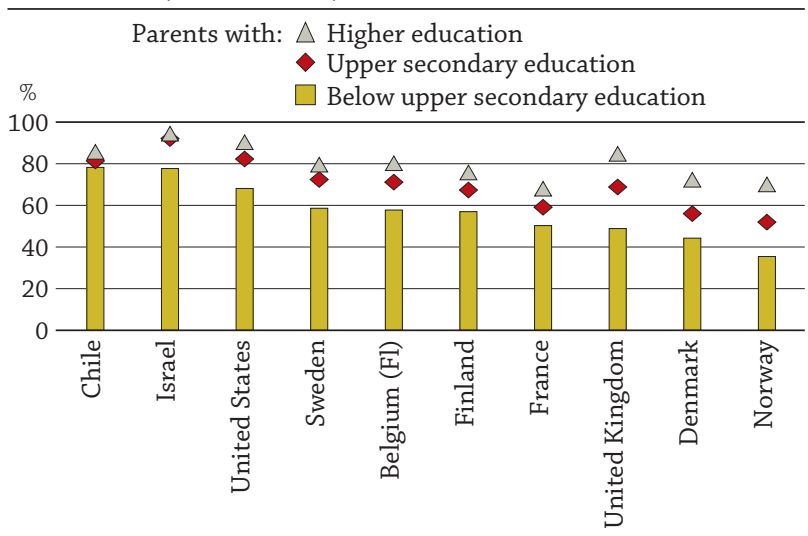

Countries are ranked in descending order of the completion rate of students whose parents have below upper secondary education.

Source: OECD (2014), Education at a Glance 2014: OECD Indicators, Box A2.2. See Annex 3 for notes (www.oecd.org/edu/eag.htm).

\section{Inequality starts in earlier levels.}

Inequalities in higher education are to a great extent the consequence of accumulated inequalities in prior years, from early childhood to secondary levels of education. Inequalities in earlier levels are transmitted into higher education in at least three different ways.

First, among students in secondary education, those from disadvantaged backgrounds are more likely to be low performers in mathematics and reading. A student in the top quarter of the PISA index of economic, social and cultural status scores 39 points higher in mathematics (equivalent of nearly one year of schooling) than less advantaged students (OECD, 2013). Students of immigrant background are also less likely to perform well in PISA. In 2012, foreign-born children lagged 21 points behind the offspring of native-born parents in reading literacy (OECD/European Union, 2015). Differences in performance and qualifications are often the main reason why students from disadvantaged backgrounds are unable to access higher education. In fact, lower qualifications are likely to play a greater role in reducing access to higher education than affordability.

Second, students whose parents have lower educational attainment are less likely to complete upper secondary education - thus making them less likely to ever access higher education. The difference in upper secondary completion rates between students from families where parents have a higher education and those from families where parents have no more than a lower secondary education ranges from 7 percentage points in Chile to more than 30 percentage points in Norway and the United Kingdom (Figure 2). Likewise, students with an immigrant background are also less likely to complete upper secondary education (OECD, 2014). 
Third, 15-year-olds from disadvantaged backgrounds are considerably less likely even to aspire to higher education. It is striking that, in all countries, aspirations for higher education are greater for 15-year-olds living in more advantaged families (Figure 3). Students in the bottom third of the PISA index of economic, social and cultural status are, on average, 37 percentage points less likely to expect to complete a university degree than students in the top third of this scale. This difference is more than 20 percentage points in every country and ranges from over 50 points in Hungary to 22 points in Trinidad and Tobago (OECD, 2012). Notably, the difference in aspirations remains very large even once we account for their performance in reading and mathematics in PISA, indicating that background affects access to higher education beyond its impact on performance.

\section{Figure 3. Percentage of students who expect to complete a university degree, by socio-economic status (ESCS*), PISA 2009}

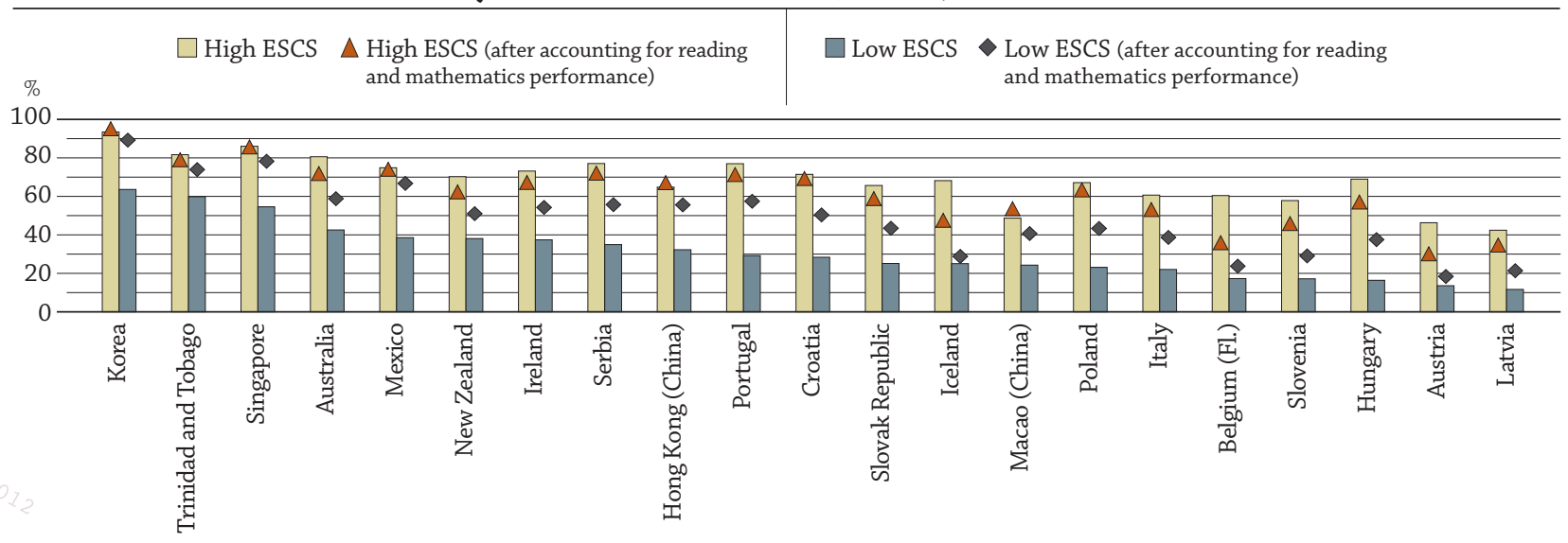

*ESCS refers to the PISA index of economic, social and cultural status. See Volume II of the PISA 2012 Results for more information.

Countries are ranked in descending order of the percentage of students with a low ESCS who expect to complete a university degree.

Source: OECD (2012), Grade Expectations: How Marks and Education Policies Shape Students' Ambitions, PISA, http://dx.doi.org/10.1787/9789264187528-en.

What can be done in higher education?

Although tackling inequalities in earlier levels of education must be a priority, higher education policies are still needed to ensure that earlier inequalities are not reinforced. Attracting a broader cross-section of society into higher education, including disadvantaged and vulnerable groups, and reducing dropout rates have both been identified as key targets within the key documents of the Europe 2020 strategy for growth and jobs ${ }^{1}$ and the strategic framework for European co-operation in education and training. ${ }^{2}$

So what would be an effective higher education policy? Contrary to traditional views, policies to lower tuition fees only have a very weak impact on equality, and tend to only work in the bottom section of the income distribution. By analysing the relationship between tuition fees, student support systems and student participation in higher education, it is clear that while high tuition fees can raise barriers to student participation, lower fees do not guarantee greater access. Student financial support systems, offering loans with repayment contingent on income combined with means-tested grants, can play an important role in promoting access and equity while sharing the costs of higher education between the state and students (OECD, 2014). Better support mechanisms, active recruitment policies and strong links with the community, are a few examples of more interesting forms of policy.

Some steps have been taken recently to decrease inequalities in higher education through different national access policies. For example, Brazil passed a law in 2012 reserving 50\% of the places in the federal universities and federal institutions of higher education (which are generally the most prestigious and selective) for students who completed their upper secondary education in public schools. Of these, half are reserved for students who also have a family per capita income of less than 1.5 times the minimum salary.

1. Europe 2020 , European Commission, http://ec.europa.eu/europe2020/index en.htm.

2. Strategic framework - Education \& Training 2020, European Commission, http://ec.europa.eu/education/policy/strategic-framework/index_en.htm. 
At the institutional level, there are several examples of alternative admissions procedures that aim to increase the access of students from disadvantaged backgrounds. One example is Sciences Po Paris, which in 2001 established the Conventions d'éducation prioritaire. This measure establishes a different admissions procedure for students that come from schools that face social difficulties (France's Zone Prioritaire), thus creating more diversity in the institution.

These examples mainly concern increasing access to higher education for students from disadvantaged socioeconomic backgrounds. Although facilitating access tends to be the focus of higher education policies for equity, access to higher education does not guarantee attainment of a degree, because students from disadvantaged backgrounds are more likely to drop out. Therefore, policies increasing access must be combined with policies aimed at increasing the successful completion of higher education.

Some institutions, NGOs or local associations try to improve the success of those students once they are in higher education by providing them with additional resources. The Europe 2015 Forum of Alpbach ${ }^{3}$ highlighted several projects from across Europe that hope to remove stumbling blocks for less-advantaged students. Examples include providing mentors to help first-generation college students, offering additional courses and tutoring sessions, and intensive language classes for students with immigrant backgrounds.

3. Higher Education Symposium, European Forum Alpbach 2015, www.alpbach.org/en/event/higher-education-symposium/.

The bottom line: The path to higher education continues to be less straightforward for young people from disadvantaged backgrounds. The expansion of higher education in the last decades has created more opportunities, but the few pieces of evidence we have suggest that significant inequalities in higher education remain. In addition to harming the ideals of fairness and justice, such inequalities have economic and social costs for countries as they imply a large waste of talents. Therefore, policies must be implemented both in earlier levels of education and in higher education itself in order to help students from disadvantaged backgrounds access and successfully complete higher education.

\section{For more information}

Aina, C. (2010), "University drop-out in Italy", Working Papers, No. 134, SEMEQ Department, Faculty of Economics, University of Eastern Piedmont. OECD (2015), Education at a Glance Interim Report: Update of Employment and Educational Attainment Indicators, OECD, Paris.

OECD (2014), Education at a Glance 2014: OECD Indicators, OECD Publishing, Paris.

OECD (2013), PISA 2012 Results: Excellence through Equity (Volume II): Giving Every Student the Chance to Succeed, PISA, OECD Publishing, Paris. OECD (2012), Grade Expectations: How Marks and Education Policies Shape Students' Ambitions, PISA, OECD Publishing, Paris. OECD/European Union (2015), Indicators of Immigrant Integration 2015: Settling In, OECD Publishing, Paris.

Thomas, L. and J. Quinn (2006), First Generation Entry into Higher Education: An International Study, Open University Press, Buckingham.

\section{Contact}

Corinne Heckmann (Corinne.HECKMANN@oecd.org) / Camila de Moraes (Camila.DEMORAES@oecd.org)

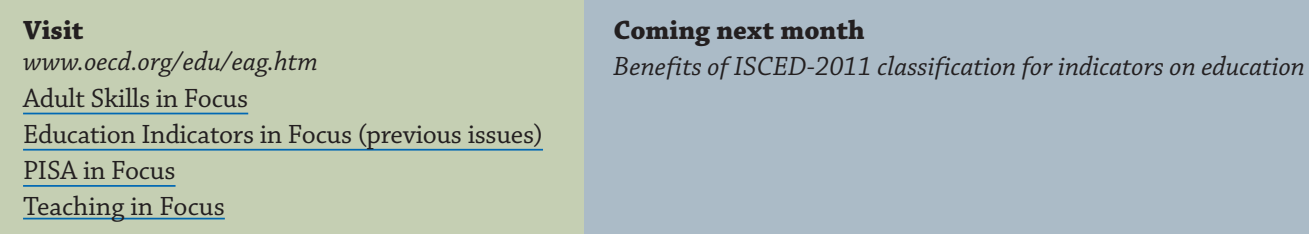

\section{Visit}

www.oecd.org/edu/eag.htm

Adult Skills in Focus

Education Indicators in Focus (previous issues)

PISA in Focus

Teaching in Focus

\section{Coming next month}

Benefits of ISCED-2011 classification for indicators on education

Photo credit: @ Ghislain \& Marie David de Lossy/Cultura/Getty Images

This paper is published under the responsibility of the Secretary-General of the OECD. The opinions expressed and arguments employed herein do not necessarily reflect the official views of OECD member countries.

This document and any map included herein are without prejudice to the status of or sovereignty over any territory, to the delimitation of international frontiers and boundaries and to the name of any territory, city or area.

The statistical data for Israel are supplied by and under the responsibility of the relevant Israeli authorities. The use of such data by the OECD is without prejudice to the status of the Golan Heights, East Jerusalem and Israeli settlements in the West Bank under the terms of international law.

Note for the Russian Federation in the Survey of Adult Skills (PIAAC)

Readers should note that the sample for the Russian Federation does not include the population of the Moscow municipal area. The data published, therefore, do not represent the entire resident population aged 16-65 in Russia but rather the population of Russia excluding the population residing in the Moscow municipal area. More detailed information regarding the data from the Russian Federation as well as that of other countries can be found in the Technical Report of the Survey of Adult Skills. 